\title{
Precursors of Antarctic Bottom Water formed on the continental shelf off Larsen Ice Shelf
}

\author{
M. van Caspel ${ }^{\mathrm{a}, *}$, M. Schröder ${ }^{\mathrm{a}}$, O. Huhn ${ }^{\mathrm{b}}$, H.H. Hellmer ${ }^{\mathrm{a}}$ \\ a Alfred Wegener Institute, Bussestrasse 24, D-27570 Bremerhaven, Germany \\ ${ }^{\mathrm{b}}$ University of Bremen, Germany
}

\section{A R T I C L E I N F O}

\section{Article history:}

Received 18 July 2014

Received in revised form

7 January 2015

Accepted 14 January 2015

Available online 24 January 2015

Keywords:

Antarctic Bottom Water

Weddell Sea

Larsen Ice Shelf

Formation of Weddell Sea Deep Water

\begin{abstract}
A B S T R A C T
The dense water flowing out from the Weddell Sea significantly contributes to Antarctic Bottom Water (AABW) and plays an important role in the Meridional Overturning Circulation. The relative importance of the two major source regions, the continental shelves in front of Filchner-Ronne Ice Shelf and Larsen Ice Shelf, however, remains unclear. Several studies focused on the contribution of the Filchner-Ronne Ice Shelf region for the deep and bottom water production within the Weddell Gyre, but the role of the Larsen Ice Shelf region for this process, especially the formation of deep water, remains speculative. Measurements made during the Polarstern cruise ANT XXIX-3 (2013) add evidence to the importance of the source in the western Weddell Sea. Using Optimum Multiparameter analysis we show that the dense water found on the continental shelf in front of the former Larsen A and B together with a very dense water originating from Larsen $C$ increases the thickness and changes the $\theta / \mathrm{S}$ characteristics of the layer that leaves the Weddell Sea to contribute to AABW.
\end{abstract}

(c) 2015 Elsevier Ltd. All rights reserved.

\section{Introduction}

The Southern Ocean is the source of the Antarctic Bottom Water (AABW). This water mass fills most of the global ocean abyss and thus plays a crucial role in the Meridional Overturning Circulation. As a key feature for the global circulation, changes in the production rates or in the main characteristics of the AABW may impact the circulation in all oceans (e.g., Lumpkin and Speer, 2007).

The most important fraction of AABW comes from the Weddell Sea Deep Water (WSDW) (e.g., Orsi et al., 1999). This water mass is formed by the mixing of Warm Deep Water (WDW) with Weddell Sea Bottom Water (WSBW) or with dense shelf waters. The continental shelf in front of Filchner-Ronne Ice Shelf (FRIS) is described as the main region where WSDW and WSBW are formed (Foldvik and Gammelsrød, 1988; Foldvik et al., 2004; Nicholls et al., 2009).

Nevertheless, there is multiple evidence that the Larsen Ice Shelf (LIS) area also contributes, at least intermittently, to WSDW (Gordon et al., 1993, 2001; Fahrbach et al., 1995; Gordon, 1998; Schröder et al., 2002; Nicholls et al., 2004; Absy et al., 2008; Huhn et al., 2008; Jullion et al., 2013). Understanding how the WSDW

\footnotetext{
* Corresponding author.

E-mail addresses: Mathias.van.Caspel@awi.de (M.v. Caspel), Michael.Schroeder@awi.de (M. Schröder), ohuhn@uni-bremen.de (O. Huhn), Hartmut.Hellmer@awi.de (H.H. Hellmer).
}

from different sources contributes to AABW is an important step to comprehend the changes that occur in the deep ocean (e.g., Azaneu et al., 2013; Purkey and Johnson, 2013).

Dense waters formed on the LIS continental shelf are found at shallower levels of the open ocean water column than those originated from FRIS, $1000 \mathrm{~km}$ further upstream (Fig. 1 in Gordon et al., 2001). Because of bathymetric constraints, this water can leave the Weddell Sea easier. The passages connecting the Weddell Sea and the Scotia Sea are less than 3500 m deep and restrict the flow into the Scotia Sea (Naveira Garabato et al., 2002; Franco et al., 2007). A high variability was observed in waters able to cross the South Scotia Ridge to produce AABW (Schröder et al., 2002), the authors suggest that the changes were caused not only by temporal fluctuations but also by the intermittent contribution of dense water masses from the Larsen region.

Fahrbach et al. (1995) compared a section in front of Larsen C and one close to the tip of the Antarctic Peninsula (AP) and observed a freshening and warming of the deep and bottom water found on the slope of the northern section. They argued that these changes were caused by a mixture of LIS shelf waters with WDW. Gordon et al. (2001) observed a fresher and more ventilated type of WSDW (VWSDW) and WSBW (VWSBW) south of the South Orkney Plateau both formed by the interaction between shelf water from the Antarctic Peninsula and WSDW. The authors suggest that the VWSBW is produced at a site more to the south with a stronger component of WSDW than the VWSDW. 


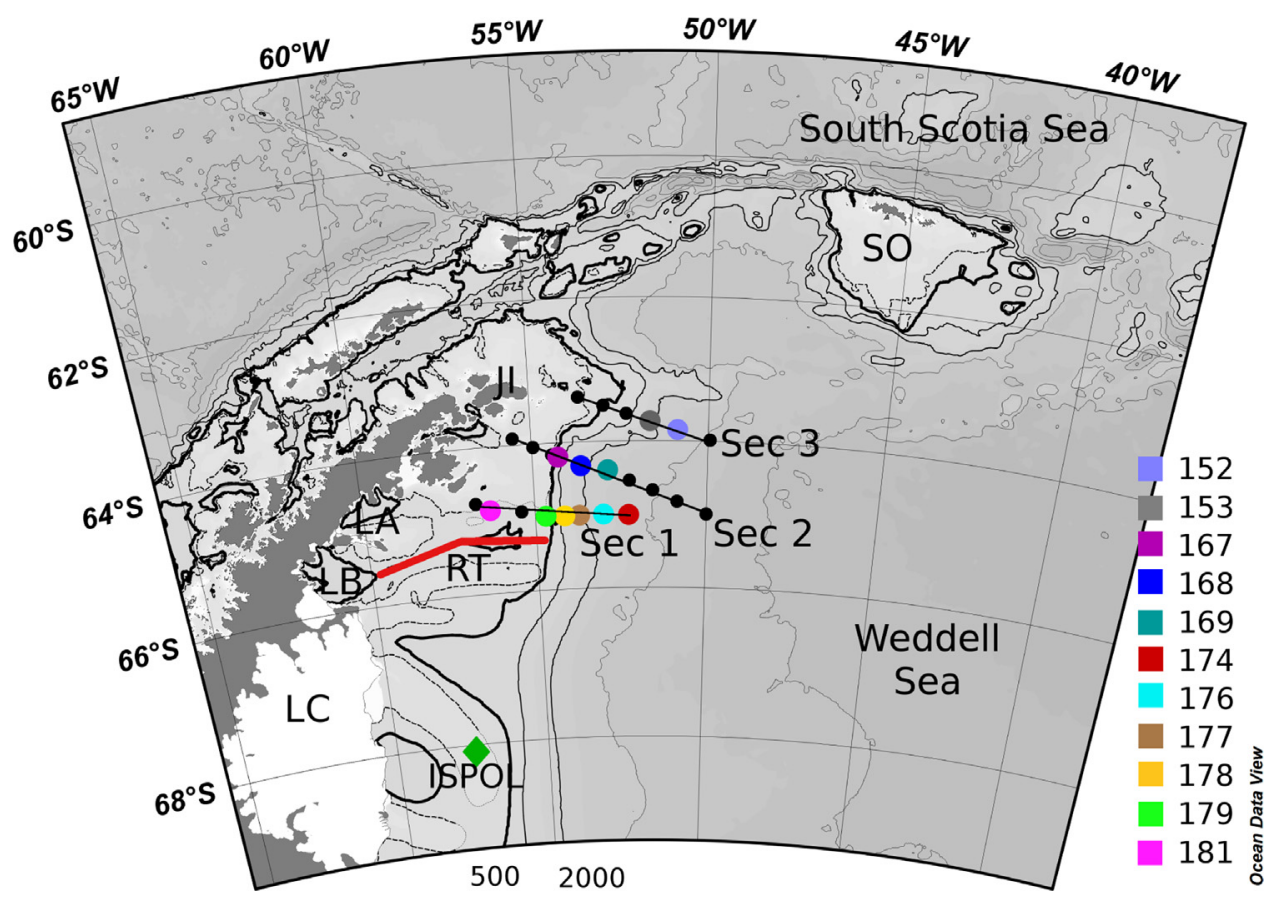

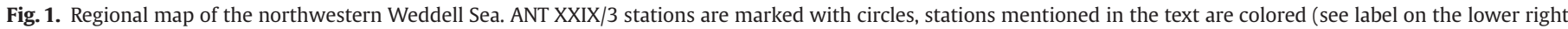

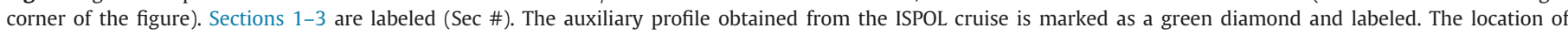

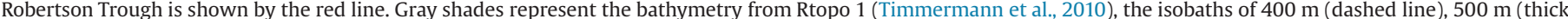

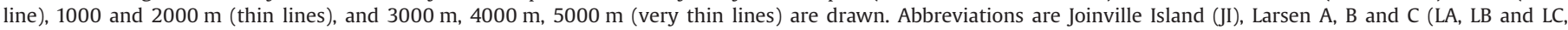

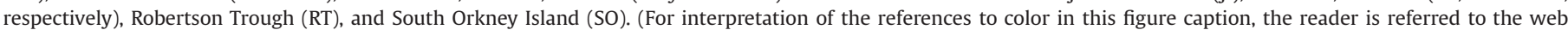
version of this paper.)

Measurements made in March 2002 on the shelf just north of Larsen $C$ revealed the presence of water colder than the surface freezing point, originating from the interaction with the ice shelf (Nicholls et al., 2004). Hydrographic data from 2004 to 2005 collected during the Ice Station Polarstern (ISPOL) drift experiment (Hellmer et al., 2008) also showed evidence for dense water production in this region and revealed the presence of lenses of relatively salty and cold waters on the continental slope at a depth of $1600 \mathrm{~m}$ (Absy et al., 2008). Optimum Multiparameter (OMP) analysis using temperature, salinity, and noble gas observations together with chlorofluorocarbons (CFCs) as age tracers supported the hypothesis of a nearby source (Huhn et al., 2008).

In this paper we present conclusive evidence for the production of a precursor water type of AABW in the LIS region. Besides, we reinforce the idea that this contribution can be related to two (or more) sources within this area. To do this, we analyzed oceanographic data obtained during summer 2013 on Polarstern Cruise ANT XXIX/3 (Gutt et al., 2013); Polarstern Cruise reports can be found at http:// www.pangaea.de/PHP/CruiseReports.php?b=Polarstern.

\section{Hydrographic data}

The goal of the Polarstern cruise ANT XXIX/3 (January to March 2013) was to perform a multidisciplinary investigation in the area of the former Larsen A and B Ice Shelves together with a krill census. In addition, an extensive hydrographic and bathymetric investigation was planned for the shelf and slope in front of the Larsen C Ice Shelf (Knust, 2012) (http://epic.awi.de/31329/7/ ANT-XXIX_1-3.pdf). Unfortunately, the initial plans had to be changed due to the severe sea-ice conditions (Gutt et al., 2013).

The main oceanographic goal was the investigation of dense water production in the LIS area. Therefore, three hydrographic sections were performed in the northwestern Weddell Sea (Fig. 1) almost perpendicular to the continental slope to a depth of
$3000 \mathrm{~m}$. Although other casts were performed during the cruise, this work mainly discusses these three sections.

The data analysis is focused on the dense waters, defined here as all waters with a neutral density $\left(\gamma^{n}\right)$ greater than $28.27 \mathrm{~kg} \mathrm{~m}^{-3}$. This value was chosen because it was used in other works to define the interface between WDW and WSDW (e.g., Fahrbach et al., 2011), and also the upper limit of AABW originating from the Weddell Sea (Orsi et al., 1999). The $\gamma^{n}$ of $28.4 \mathrm{~kg} \mathrm{~m}^{-3}$ was used to separate WSDW from WSBW. Nevertheless, the names WSDW and WSBW are misleading when used for waters found in shallow areas, like the continental shelf. To avoid the depth association we used the terms Neutral Deep Water $\left(\mathrm{DW} \gamma^{n}\right)$ to refer to waters in the $\gamma^{n}$-range from 28.27 to $28.4 \mathrm{~kg} \mathrm{~m}^{-3}$, and Neutral Bottom Water $\left(\mathrm{BW} \gamma^{n}\right)$ for $\gamma^{n}$ higher than $28.4 \mathrm{~kg} \mathrm{~m}^{-3}$. The new terms are especially useful to discuss the mixing processes occurring at the shelf break and on the slope. The abbreviations used for all water masses are summarized in Table 1 .

\subsection{Data quality}

The hydrographic measurements during ANT XXIX/3 were made using a SBE $911+$ CTD connected to a carrousel with 24 bottles of $12 \mathrm{~L}$. The sensors attached to the system were two conductivity and temperature sensors, a pressure sensor, one oxygen sensor, a transmissometer, a fluorometer, and an altimeter. More details about the sensors are found in Gutt et al. (2013).

The conductivity and temperature sensor calibrations were performed before and after the cruise at Seabird Electronics. The accuracy of the temperature sensors is $2 \mathrm{mK}$. The readings of the pressure sensor have precision and accuracy better than $1 \mathrm{dbar}$ The conductivity was corrected using salinity measurements from water samples. IAPSO Standard Seawater from the P-series P154 $(K 15=0.99990$, practical salinity 34.996$)$ was used. A total of 98 water samples were measured using an Optimare Precision Salinometer OPS 006. On the basis of the water sample correction 
Table 1

Abbreviations used.

\begin{tabular}{ll}
\hline Abbreviation & Meaning \\
\hline WDW & Warm Deep Water \\
mWDW & Modified Warm Deep Water \\
WSDW & Weddell Sea Deep Water \\
WSBW & Weddell Sea Bottom Water \\
LABW & Dense water observed on the shelf in front of Larsen A and B \\
LCW & Dense water observed on the shelf in front of Larsen C \\
DW $\gamma^{n}$ & Neutral Deep Water; covers the WSDW and the waters on the shelf and slope with $\gamma^{n}$ between 28.27 and $28.4 \mathrm{~kg} \mathrm{~m}^{-3}$ \\
BW $^{n}$ & Neutral Bottom Water; covers the WSDW and the waters on the shelf and slope with $\gamma^{n}$ values higher than $28.4 \mathrm{~kg} \mathrm{~m}^{-3}$ \\
$*^{S W T}$ & Used to refer to the Source Water Type representing an water mass (*) \\
\hline
\end{tabular}

and sensor recalibration, salinity is measured to an accuracy of 0.002 (Schröder et al., 2013a).

The oxygen was corrected from water samples using the Winkler method with a Dissolved Oxygen Analyzer (DOA,SIS type). In total, 217 water samples were measured from 25 stations, which were used to correct a small trend observed in the sensor measurements so that the final error was $1.34 \mu \mathrm{mol} \mathrm{kg} \mathrm{kg}^{-1}$ (Schröder et al., 2013b).

In addition to temperature, salinity, and oxygen, we used noble gas measurements to reinforce the OMP results. Water samples were taken from the CTD bottles using gas-tight copper tubes. They were measured by mass spectrometry at the IUP Bremen (Sültenfuß et al., 2009) for helium (He) isotopes and neon (Ne) with an accuracy of $1 \%$.

Data from a cast (station 003-1) performed on December, 2004 during ISPOL was also considered. This station is located close to the shelf break in front of Larsen $C$ and covers the temperature and salinity range necessary to produce the salty and cold WSBW observed during the cruise (Absy et al., 2008). The ISPOL cast was made using a CTD system carried by helicopter. The obtained accuracies were 0.005 (salinity), 0.003 (temperature), and $3 \mathrm{dbar}$ (pressure). A Niskin bottle was used to take a water sample close to the bottom, which was analyzed for the He and Ne concentrations (Huhn et al., 2008).

\subsection{Observations}

The entire region was occupied by cold $(\theta=-1.8)$ and fresh $(\mathrm{S}<34.4)$ surface water (Antarctic Surface Water) underlaid by slightly saltier $(S=34.45$ ) Winter Water (WW). The WDW is found below this level at stations deeper than $1000 \mathrm{~m}$. The depth of the maximum temperature decreases with increasing distance from the shelf break and varies between 200 and $500 \mathrm{~m}$. WSDW and WSBW are present beneath the WDW layer (Figs. 2-4).

Between the shelf break and the 1000-m isobath, the intermediate and bottom layers are filled with a mixture of shelf and ambient waters, i.e., WDW or WSDW, depending on the depth and position in the water column. The mixing products of this interaction are modified WDW, DW $\gamma^{n}$ (gray line in Figs. 2-4), and $\mathrm{BW} \gamma^{n}$ (black line in Fig. 2), which is a derivative from the dense water observed on the continental shelf along this section (Fig. 2). In Sections 2 and $3 \mathrm{BW} \gamma^{n}$ is not present at this shallow depth.

On the southern most section on the shelf, station 181 has the thickest BW $\gamma^{n}$ layer. Towards the shelf break (\#181 to \#179) this layer gets thinner $(96.9,66.3,49.4 \mathrm{~m})$, warmer (mean $\theta$ : -1.841 , $-1.829,-1.654{ }^{\circ} \mathrm{C}$ ) and saltier (mean S: $34.555,34.555,34.573$ ) while the oxygen values decline (mean $\mathrm{O}_{2}: 296.865,295.650$, $288.813 \mu \mathrm{mol} \mathrm{kg}^{-1}$ ). Station 182 is located on the northern slope of the Robertson Trough (Fig. 1). Thus, it is shallower than the other stations, and has a thinner $\mathrm{BW} \gamma^{n}$-layer, which is concentrated on the deep portions of the trough; Robertson Trough is a depression on the continental shelf that connects the area of the
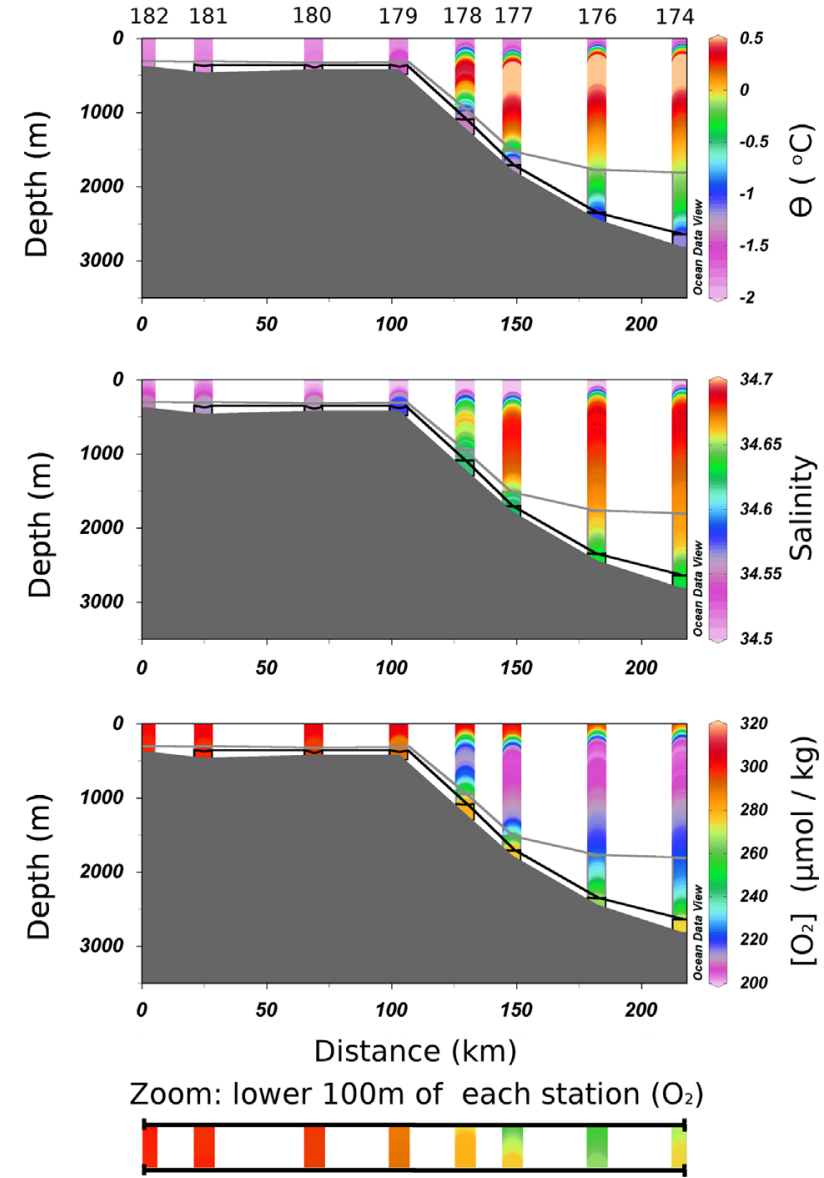

Fig. 2. Section 1 measured values of potential temperature $\left({ }^{\circ} \mathrm{C}\right.$, top), salinity (middle), and oxygen concentration ( $\mu \mathrm{mol} \mathrm{kg}{ }^{-1}$, bottom) as represented by the colors. Station numbers are displayed on top of the first figure. The gray line represents neutral density $\left(\gamma^{n}, \mathrm{~kg} \mathrm{~m}^{-3}\right)$ of 28.27 and the black line of 28.4. The bathymetry corresponds to the bottom depth taken from the casts. The oxygen concentration of the lower $100 \mathrm{~m}$ is shown in the lower part of the bottom figure. (For interpretation of the references to color in this figure caption, the reader is referred to the web version of this paper.)

former LIS-B with the shelf break, and is also connected to a channel coming from the former LIS-A region (e.g., Evans et al., 2005). The deepest part of the depression is not connected to the shelf break and might be a reservoir of dense water.

Waters with similar characteristics were observed in Robertson Trough in October, 2006 (Lemke, 2009) and in February, 2009 (ATOS2), but they showed a colder and saltier bottom layer. The differences can be caused by seasonal and interannual variability, changes in the pulses of dense water outflow, and/or the older measurements were made closer to the reservoir. The deep troughs found on the continental shelf formerly covered by LIS-A 

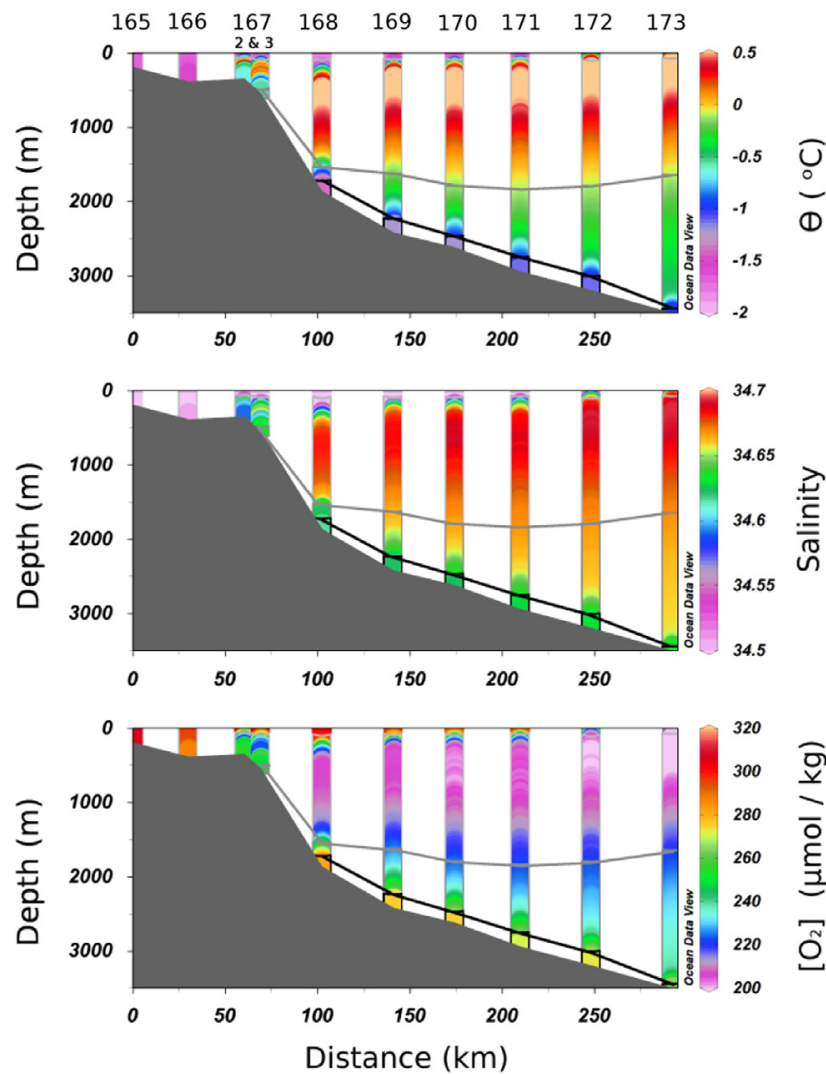

Fig. 3. Section 2 measured values of potential temperature $\left({ }^{\circ} \mathrm{C}\right.$, top), salinity (middle), and oxygen concentration ( $\mu \mathrm{mol} \mathrm{kg}{ }^{-1}$, bottom) as represented by the colors. Station numbers are displayed on top of the first figure. The gray line represents neutral density $\left(\gamma^{n}, \mathrm{~kg} \mathrm{~m}^{-3}\right)$ of 28.27 and the black line of 28.4. The bathymetry corresponds to the bottom depth taken from the casts. (For interpretation of the references to color in this figure caption, the reader is referred to the web version of this paper.)

and B (e.g., Arndt et al., 2013) are possible sources for these pulses since the dense-water layer is much thicker (Graeve et al., 2013). However, because of the bathymetric restrictions, only by mixing with the shallower waters can the dense water leave these basins and spill into the Robertson Trough.

Further north, in Sections 2 and 3, no BW $\gamma^{n}$ was detected on the shelf (black line in Figs. 3 and 4), providing additional evidence that the dense water is guided to the slope by local bathymetry. Following the shelf break downstream, part of the $\mathrm{BW} \gamma^{n}$ observed at \# 179 is converted into $\mathrm{DW} \gamma^{n}$ in Section 2 (\#167-3), likely due to further mixing with WDW. The temperature, salinity and oxygen profiles of the DW $\gamma^{n}$ from \#167 (purple arrow in Fig. 5) resemble the thin layer of fresh, cold, and ventilated water, respectively, observed offshore in the WSDW layer at $1600 \mathrm{~m}$ depth (\#168, blue arrow in Fig. 5). To the south, in Section 1, a similar feature is observed at a depth of $1000 \mathrm{~m}$ (\#178, yellow arrow in Fig. 5).

The stations with the intrusions (\#168 and \#178) show the densest bottom water sampled during the cruise. The bottom $\theta / \mathrm{S}$ values are almost the same (Fig. 5) and the oxygen is the highest observed in offshore deep waters (Figs. 2-4). These similarities suggest that both have the same origin and are flowing downslope.

Additional evidence that WSDW and WSBW are produced on the northwestern Weddell Sea is the increase of the dense layer thickness along the $1800-\mathrm{m}$ isobath (\#153, \#168, and \#177) (Fig. 6). From Sections 1 and 2 the thickness increased from 261 to $325 \mathrm{~m}$, reaching $452 \mathrm{~m}$ in Section 3. Comparing the vertical profiles of the three stations, a northward freshening, cooling, and oxygen increase can be observed below $1000 \mathrm{~m}$ almost down to the sea
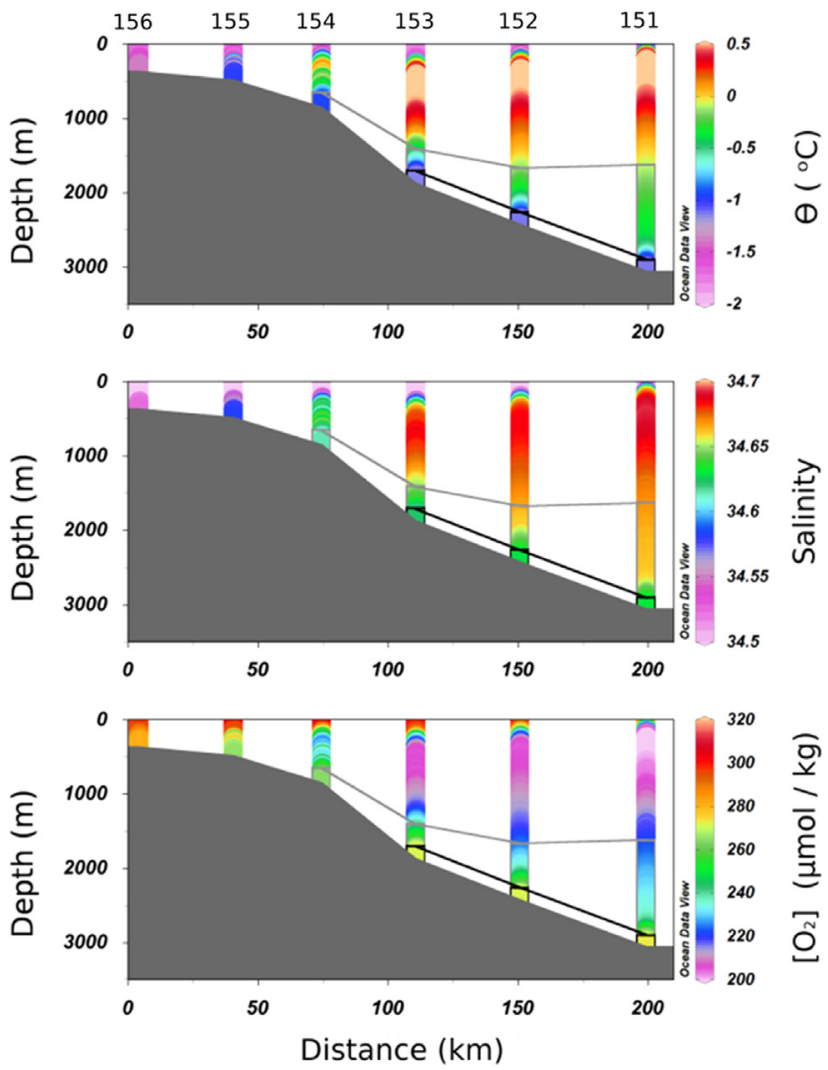

Fig. 4. Section 3 measured values of potential temperature $\left({ }^{\circ} \mathrm{C}\right.$, top), salinity (middle), and oxygen concentration ( $\mu \mathrm{mol} \mathrm{kg}^{-1}$, bottom) as represented by the colors. Station numbers are displayed on top of the first figure. The gray line represents neutral density $\left(\gamma^{n}, \mathrm{~kg} \mathrm{~m}^{-3}\right)$ of 28.27 and the black line of 28.4. The bathymetry corresponds to the bottom depth taken from the casts. (For interpretation of the references to color in this figure caption, the reader is referred to the web version of this paper.)

floor (Figs. 5 and 6). High gradients are found close to the bottom between Sections 1 and 2, but this change is followed by a warming and oxygen reduction on the northern section (Figs. 5 and 6).

The existence of thin layers with different properties (Fig. 5), the deepening of the densest water, and the increase of the dense layer thickness point to a nearby source. This will be investigated in the next section using the OMP analysis.

\section{Optimum Multiparameter (OMP) analysis}

OMP is a method used to determine the mixture fractions $\left(f_{i}\right)$ of predefined source water types (SWT) to produce the characteristics of an observed water particle $\left(X_{o b s}\right)$ (Tomczak, 1981; Mackas et al., 1987; Tomczak and Large, 1989; Huhn et al., 2008; Frants et al., 2013). The method assumes a linear mixing combination of the $\mathrm{SWT}_{i}$ properties $\left(X_{i}\right)$ (Eq. (1)) and mass conservation (Eq. (2)); all $f_{i}$ should be positive.

$X_{o b s}=\sum f_{i} X_{i}$

$\sum f_{i}=1$

The number of SWT that can be considered must be equal or smaller than the number of conservative properties analyzed plus one. Inverting this equation system by minimizing the deviations between observed and computed properties (Eq. (3)) in a least square sense yields the optimum combination of SWT fractions. The equations are normalized by the mean and the standard deviation of each property, and weighted; for more details see 

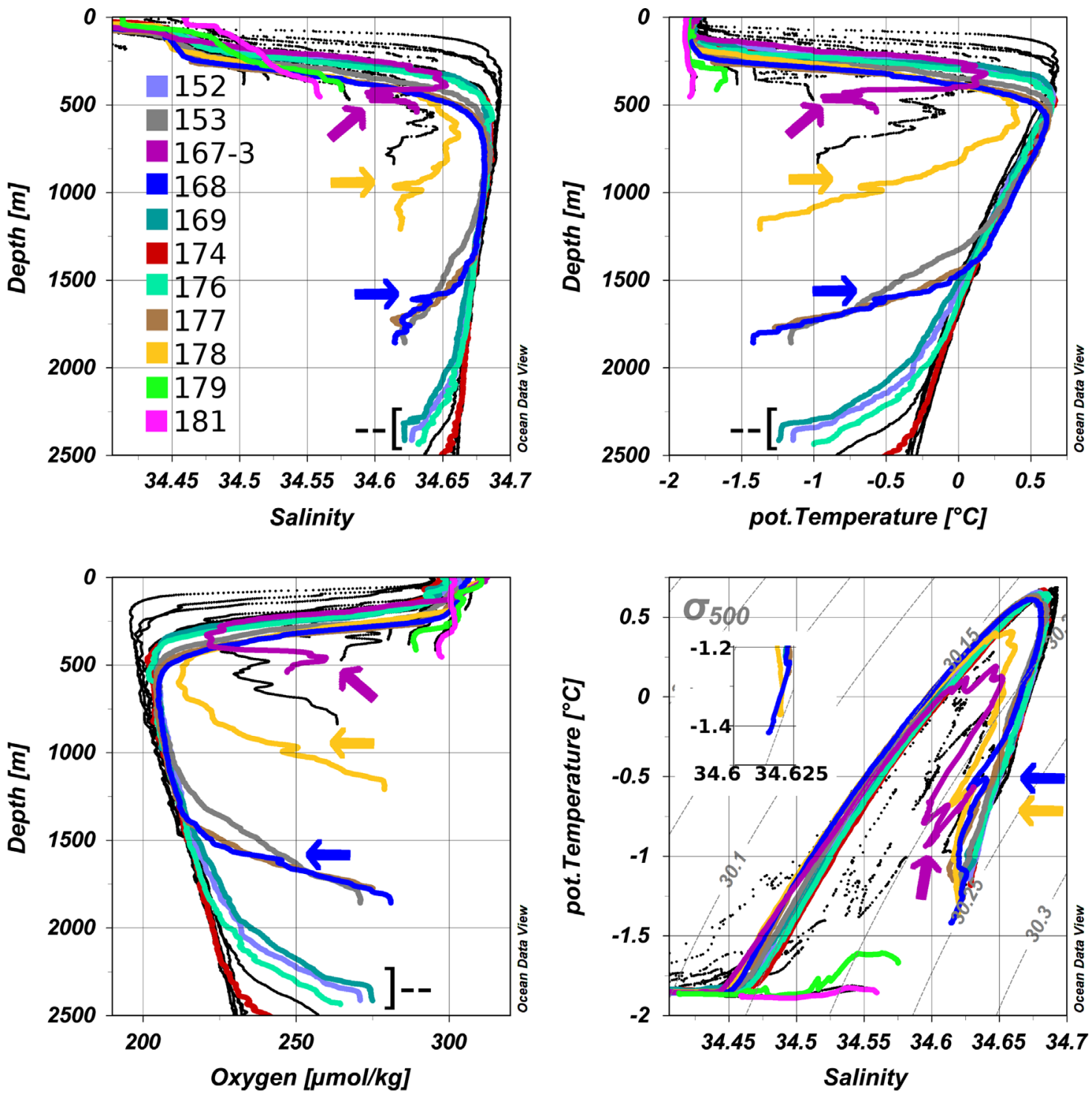

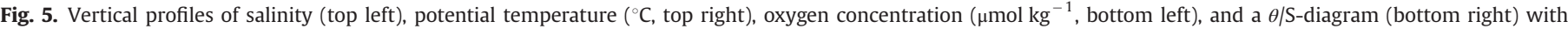

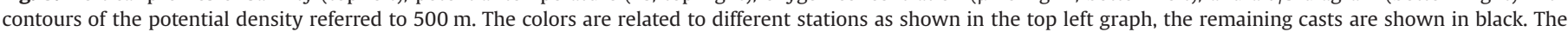

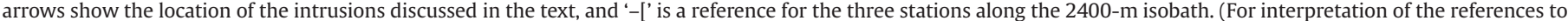
color in this figure caption, the reader is referred to the web version of this paper.)

Tomczak and Large (1989). The analysis presented here was performed based on the OMP Package for MATLAB Version 2.0 (Karstensen and Tomczak, 1995).

$R_{X}=X_{o b s}-\sum f_{i} X_{i}$

In an ideal case all measured parameters can be reproduced exactly, but usually there is some residual difference $\left(R_{X}\right)$, which we used to evaluate the quality of the results obtained. In this study we considered potential temperature $(\theta)$, salinity, and oxygen as conservative parameters. Changes in oxygen due to biogeochemical processes are expected to be small because the study is confined to a small area and the SWTs are defined from data obtained nearby. Nevertheless, we used a smaller weight for oxygen, 0.3 , than for the other parameters, 1 .

Since this work is focused on the production of WSDW and WSBW, the OMP analysis was applied only to dense waters, $\gamma^{n}$ greater than 28.27 , found offshore of the shelf break, i.e., below the gray line and to the right of \#179 (Fig. 2), \#167 (Fig. 3), and \#154 (Fig. 4).
Based on the high oxygen concentrations observed at the bottom of \#181, in the northern flank of Robertson Trough, we assume that (even) mixing with ambient water will conserve this signal. The gas content gradually reduces as the dense water flows down the continental slope along the bottom and mixes (lower part of Fig. 2), reaching its minimum value at $2400 \mathrm{~m}$ depth. We associate the increase in oxygen concentration further downslope, at $2800 \mathrm{~m}$ (\#174), with WSBW produced in the vicinity of the Filchner-Ronne Ice Shelf and suppose that the portion of this water that remained at shallower depth (Foldvik et al., 2004) is mixed with the overlaying waters (WSDW and WDW) and waters coming from the continental shelf off LIS.

Because of this evidence for a distinction between WSBW from different sources, \#174 was chosen to represent the incoming WSBW; here, the bottom value was used to define the WSBWSWT $\left(\right.$ WSBW $^{S W T}$ ) (Table 2). Hereafter, the SWT-uppercase is used to distinguish between the water masses, which have property values within a certain range, and the SWT with distinct $\theta, \mathrm{S}$, and oxygen values. 

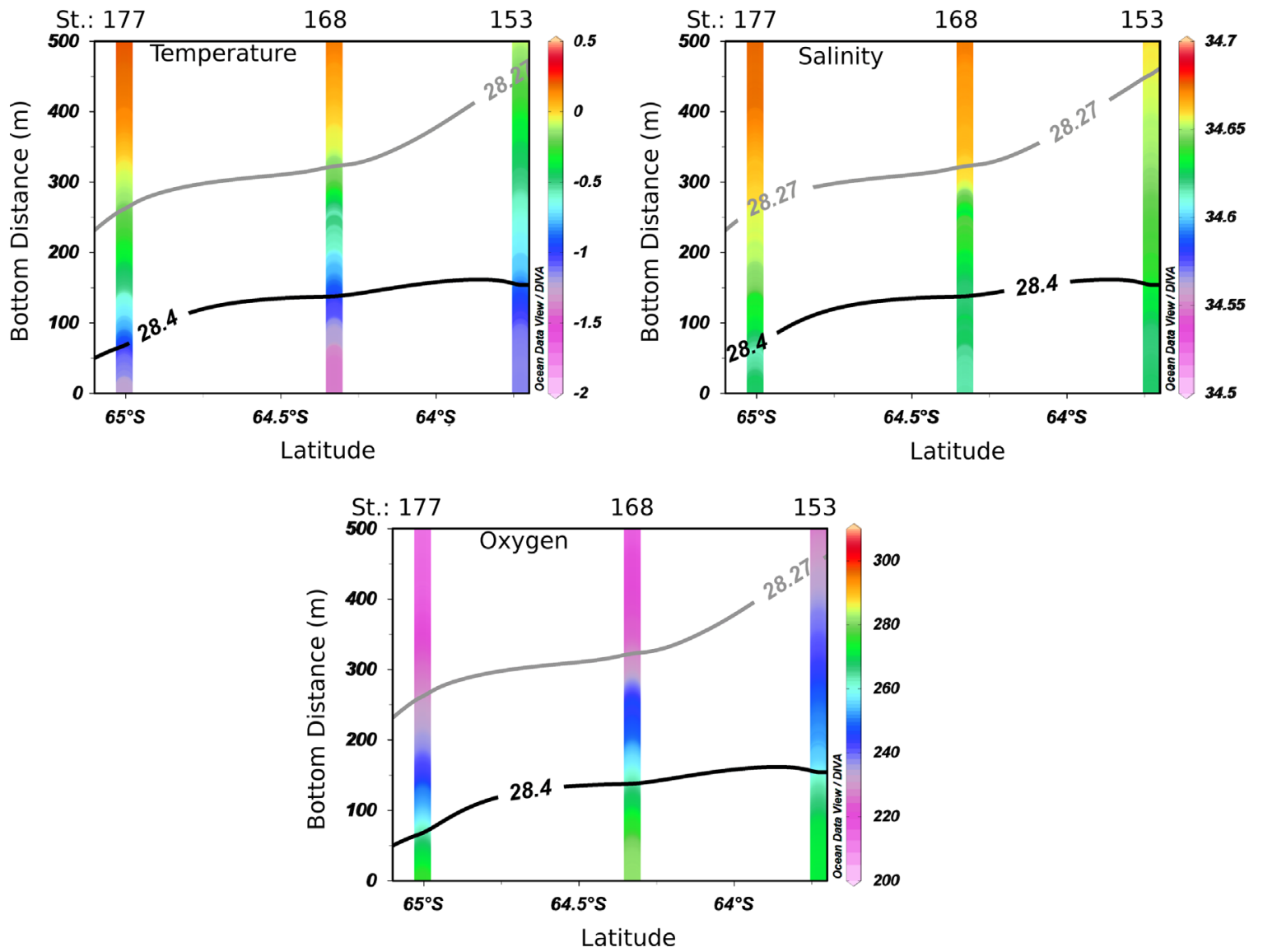

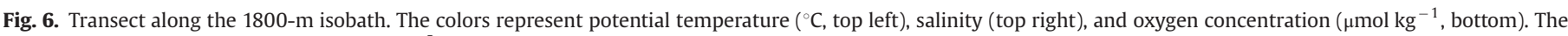

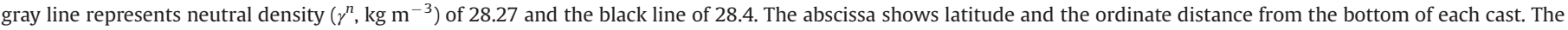
station numbers are on top of each figure. (For interpretation of the references to color in this figure caption, the reader is referred to the web version of this paper.)

Table 2

Source Water Type parameters. The standard deviation of the layers representing the Larsen waters is also shown.

\begin{tabular}{llll}
\hline SWT & $\theta\left({ }^{\circ} \mathrm{C}\right)$ & $\mathrm{S}$ & {$\left[\mathrm{O}_{2}\right]\left(\mu \mathrm{mol} \mathrm{kg}^{-1}\right)$} \\
\hline WSBW $^{\text {SWT }}$ & -1.185 & 34.629 & 273 \\
WDW $^{\text {SWT }}$ & 0.482 & 34.686 & 203 \\
LABW $^{\text {SWT }}$ & $-1.841 \pm 0.005$ & $34.555 \pm 0.003$ & $297 \pm 0.3304$ \\
LCW $^{\text {SWT }}$ & $-1.925 \pm 0.001$ & $34.640 \pm 0.009$ & 300 \\
\hline
\end{tabular}

For the $W D W^{S W T}$, the salinity maximum of the same profile (816 m depth of station 174) was selected because it can linearly mix with WSBW ${ }^{S W T}$ to produce the WSDW observed at the deeper stations (Fig. 7). Besides, as shelf water flows downslope the mixtures with water of the salinity maximum are denser than mixtures with water of the temperature maximum.

\subsection{Larsen area contribution}

We conducted the OMP analysis using WDW ${ }^{S W T}$, WSBW ${ }^{S W T}$ and a third SWT that reflects the dense water observed in the Robertson Trough, named Larsen AB Water (LABW). The LABW ${ }^{S W T}$ parameters were defined as the mean values of the $B W \gamma^{n}$ layer at \#181 (Table 2); as stated before, \#182 suffers less influence of the LABW because it is located on the northern slope of the Robertson Trough. Using the three SWTs, most of the observations can be reproduced with small $R_{X}\left(R_{\theta}<0.01, R_{S}<0.005, R_{O_{2}}<7, R_{\text {mass }}<0.0005\right)$. However, the densest waters observed could not be reproduced (yellow circle in Fig. 7), making it obvious that an additional source water mass is still missing.

As mentioned before, the deepening of this dense water between Sections 1 and 2 suggests a nearby source, but the unsatisfying OMP results indicate that it cannot be LABW. The results of previous studies (Absy et al., 2008; Huhn et al., 2008) indicate the production of WSBW in front of Larsen C. Therefore, a fourth SWT representing the Larsen C Water (LCW) was added. A satisfactory reproduction of all dense water characteristics was achieved only when considering this fourth SWT.

$\mathrm{LCW}^{S W T}$ characteristics were obtained from the ISPOL station $3-1$, with the average of the lower $100 \mathrm{~m}$ used to represent temperature and salinity (Table 2, Fig. 7). No oxygen sensor was used during the ISPOL cruise, but some water samples collected on the slope, were analyzed with the Winkler method (unpublished data, David Thomas). In the region where the bottom waters were related to the Larsen C Ice Shelf, i.e. at $1500 \mathrm{~m}$ depth (Absy et al., 2008), the oxygen values were high $\left(291-294 \mu \mathrm{mol} \mathrm{kg}^{-1}\right)$. Since the waters on the slope most likely mixed with ambient waters, we used a value of $300 \mu \mathrm{mol} \mathrm{kg}^{-1}$ to represent LCW (Table 2).

With the addition of the Larsen Waters the results in the area between the shelf break and $2000 \mathrm{~m}$ depth as well as in the bottom layer (lower $80 \mathrm{~m}$ ) of \#169 and \#152 improved in comparison to the tests without them. Although the WSBW ${ }^{S W T}$ temperature and salinity are encompassed by the other SWTs (Fig. 7) this water mass is needed to resolve the oxygen observations (not shown). The residual difference $\left(R_{X}\right)$ of the $\mathrm{BW} \gamma^{n}$-layer is comparable to the accuracy of the measurements and the standard deviation of the values chosen to represent LABW and LCW (Table 3), indicating that this level was well represented in the OMP analysis. 


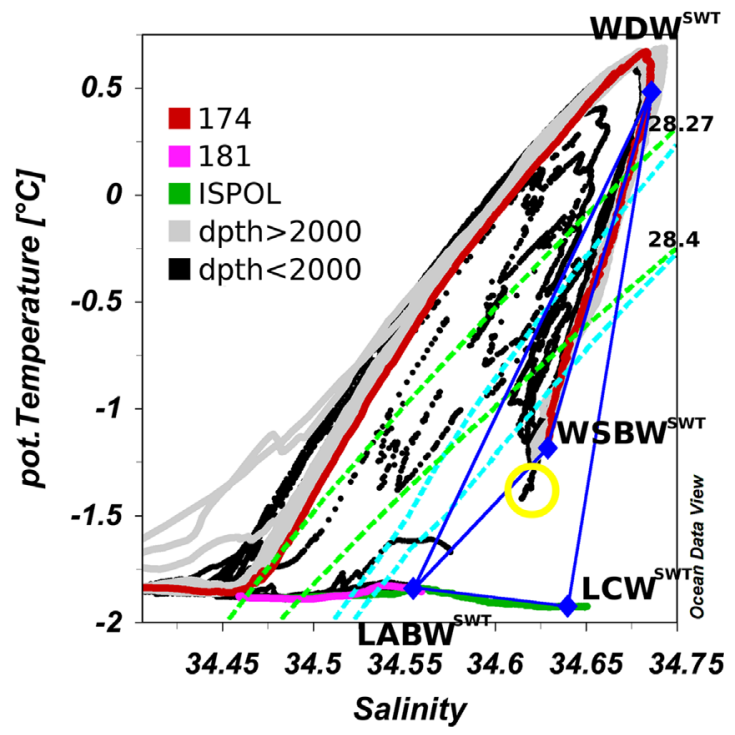

Fig. 7. $\theta /$ S-diagram showing the Source Water Types (SWT) used for the Optimum Multiparameter (OMP) analysis. The values used for OMP are marked as blue diamonds, the stations where they were measured are colored. Stations in regions deeper than $2000 \mathrm{~m}$ are shown in gray and the remaining stations are displayed black. The yellow circle shows water characteristics that cannot be reproduced using only three SWTs, see text for more details. The dashed lines are contours of neutral density referred to $500-\mathrm{m}$ (cian) a $2000-\mathrm{m}$ (light green) depth, $65^{\circ} \mathrm{S}$, and $55^{\circ} \mathrm{W}$. (For interpretation of the references to color in this figure caption, the reader is referred to the web version of this paper.)

Table 3

Residual difference maximum.

\begin{tabular}{lclll}
\hline Layer & $R_{\theta}\left({ }^{\circ} \mathrm{C}\right)$ & $R_{S}$ & $R_{\left[\mathrm{O}_{2}\right]}\left(\mu \mathrm{mol} \mathrm{kg}^{-1}\right)$ & $R_{\text {mass }}$ \\
\hline $\mathrm{BW} \gamma^{n}$ & 0.0033 & 0.0015 & 1.5 & $5 \times 10^{-5}$ \\
$\mathrm{DW} \gamma^{n}$ & 0.01 & 0.0049 & 4.8 & $14 \times 10^{-5}$ \\
st. 178 & -0.085 & 0.956 & 10.55 & 0.0275 \\
\hline
\end{tabular}

The $R_{X}$ gradually increases towards the interface with the WDW layer, reflecting the higher variability of the lighter waters involved in the production of $\mathrm{DW} \gamma^{n}$. The selection of the salinity maximum to characterize $W_{D W}{ }^{S W T}$ was essential for a good representation of the incoming WSDW, but shallower (warmer and fresher) or modified (colder and fresher) portions of this water mass may also interact with the shelf waters to produce the upper parts of WSDW layer observed on the slope. To represent all these variations of the WDW additional SWTs would be needed, but, due to the limitations of the method, we can use only one SWT to represent WDW.

The consistency of the OMP results was also checked against the tracer gases. He and Ne values from the same stations, used for the other parameters (\#181, \#174, and from ISPOL), were used for each SWT, using data from the nearest bottle. In general, the noble gas values obtained by the OMP analysis agree with the observed characteristics within the water column and the $R^{X}$ are within the accuracy of the measurements.

Several tests were performed using different values for the SWT properties and weight. These tests were performed to account for the variability in the water mass characteristics, specially concerning the $\mathrm{LCW}^{S W T}$. The use of data from a different year is not ideal so we also performed the analysis using values obtained from a cast made in 1992 (Gordon, 1998).

As mentioned before, a smaller weight was given for oxygen to account for the differences on the oxygen mixing that might be associated with the biogeochemical processes. The value was chosen because it resulted on the smaller $R^{X}$ tests with different

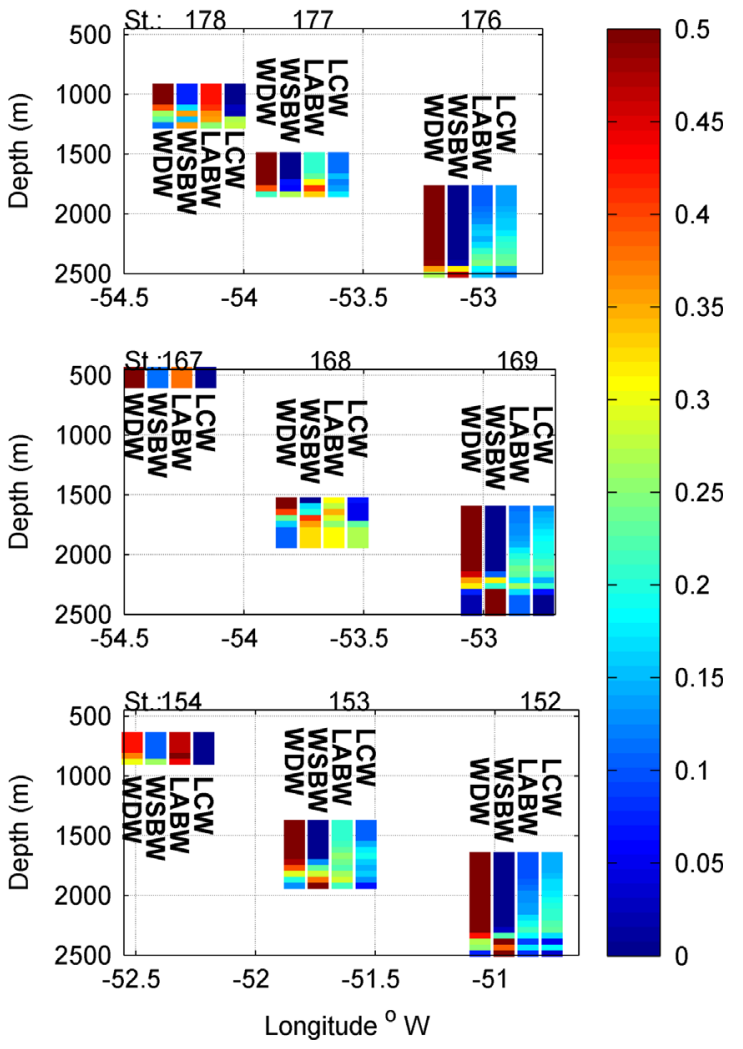

Fig. 8. Source Water Type (SWT) fractions (color shading) of the dense water layer, $\gamma^{n}>28.27 \mathrm{~kg} \mathrm{~m}^{-3}$, along the slope of Section 1 (top), Section 2 (middle), and Section 3 (bottom). Station numbers are displayed on top of the figures, and the SWT fractions at each station are, from left to right, Warm Deep Water SWT $\left(W^{S W T}\right)$, Weddell Sea Bottom Water SWT $\left(W_{S B W}^{S W T}\right)$, Larsen A and B Water SWT $\left(\mathrm{LABW}^{\mathrm{SWT}}\right)$, and Larsen C Water SWT $\left(\mathrm{LCW}^{S W T}\right)$. The contributions are averaged every $50 \mathrm{~m}$ from the bottom up. The ordinate shows the depth in $\mathrm{m}$, and the abscissa is a reference of longitude; the station is positioned where the LABW $^{S W T}$ contribution is plotted. (For interpretation of the references to color in this figure caption, the reader is referred to the web version of this paper.)

weights. We decided to use this approach instead of the variance method proposed by Tomczak and Large (1989) because we could not account for the variability of LABW and LCW due to the lack of knowledge of the source region.

Due to the large number of possible settings it is difficult to estimate the exact errors, but the general patterns of SWT distribution were kept in all the assessments we performed a deeper examination. The results mentioned before and described hereafter are the ones with the smaller $R^{X}$.

\subsection{Discussion}

The OMP results indicate a strong influence of $\mathrm{WDW}^{S W T}$ on the upper levels of the dense layer, and larger contributions of WSBW $^{S W T}$ close to the bottom of the deeper stations. In Section 1 (Fig. 8, top), the LABW ${ }^{S W T}$ dominates the shelf break and is also important on the upper slope (\#178), where the dense water observed close to the bottom is represented by a mixture of WSBW $^{S W T}$ and $\mathrm{LCW}^{\text {SWT }}$.

In Section 2 (Fig. 8, middle), the shelf break characteristics are represented by a mixture of $\mathrm{WDW}^{S W T}$ and $\mathrm{LABW}^{S W T}$. On the slope (\#168), the mean contribution of LABW ${ }^{S W T}$ is $28 \%$, and it varies between $10 \%$ and $45 \%$ if the water column is divided in $1-\mathrm{m}$ intervals (not shown); the influence of this SWT is high where the fresh intrusions (thin layers) were observed. At this station (\#168), WSBW $^{S W T}$ is the major source water between 1760 and $1820 \mathrm{~m}$ depth. Near the ocean floor (from $1820 \mathrm{~m}$ until $1860 \mathrm{~m}$ depth), it is 


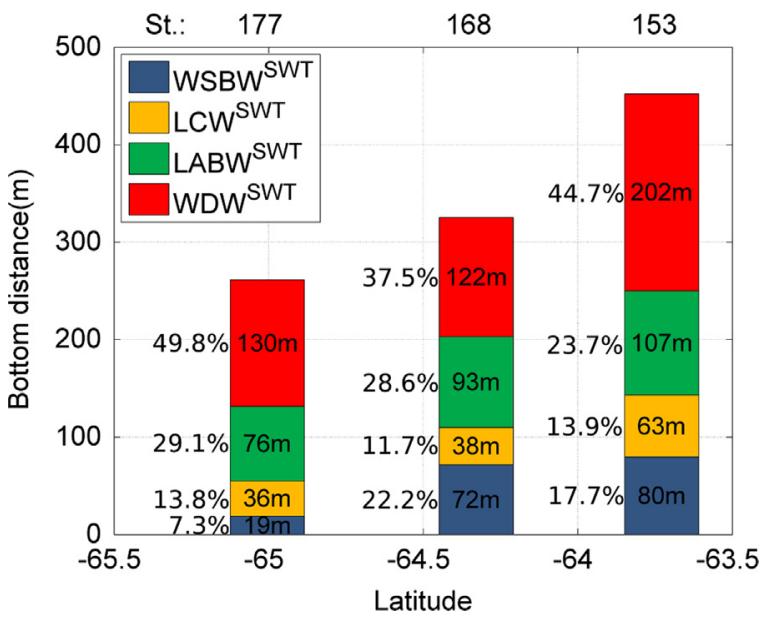

Fig. 9. Composition of the dense water layer, $\gamma^{n}>28.27 \mathrm{~kg} \mathrm{~m}^{-3}$, along the $1800 \mathrm{~m}$ isobath. The contribution of each Source Water Type (SWT) is vertically integrated and represented by the height of the colored rectangles, Warm Deep Water SWT $\left(W^{S W W} W^{S W T}\right.$, red), Larsen A and B Water SWT (LABW ${ }^{S W T}$, green), Larsen C Water SWT $\left(\mathrm{LCW}^{S W T}\right.$, yellow) and Weddell Sea Bottom Water SWT (WSBW ${ }^{S W T}$, blue); the same colors are used in Fig. 10. The numbers inside the rectangles correspond to the water column thickness in meters, and the ones to the left are the contributions of each SWT in percentage. The abscissa represents latitude and the ordinate distance from the bottom of each cast. The corresponding station numbers are on top of the figure. (For interpretation of the references to color in this figure caption, the reader is referred to the web version of this paper.)

mixed with $\mathrm{LCW}^{S W T}$ and $\mathrm{LABW}^{S W T}$ to produce the densest water observed.

Further to the north (Section 3, Fig. 8, bottom), no dense water $\left(\mathrm{DW} \gamma^{n}\right.$ ) is observed at the shelf break (Fig. 4). Next to it (\#154), the $\mathrm{DW} \gamma^{n}$ layer goes from $650 \mathrm{~m}$ depth down to the bottom $(840 \mathrm{~m})$ and consists of a mixture of WDW ${ }^{S W T}$ and LABW ${ }^{S W T}$, with small contributions of $W_{S B W}{ }^{S W T}$ in the lower $50 \mathrm{~m}$. Around $1850 \mathrm{~m}$ (\#153), LABW ${ }^{S W T}$ is widespread in the water column than in Section 2, WSBW ${ }^{S W T}$ is attached to the bottom, and $\mathrm{LCW}^{S W T}$ is more abundant between 1700 and $1800 \mathrm{~m}$.

The increase of dense layer thickness along the 1800-m isobath is caused by an increased amount of all SWTs (Fig. 9). The presence of LABW ${ }^{S W T}$ in Section 1 can be explained by the injection of this water mass at the southern margin of the Robertson Trough. The total amount of this SWT in the water column increases by $31 \mathrm{~m}$ from the southern to the northern section. The direct impact of this SWT is not very strong, but it plays a major role in the conversion of WDW to WSDW; the amount of WDW ${ }^{S W T}$ in the water column shows an increase of $72 \mathrm{~m}$. Nevertheless, mixing between the waters requires time which means that LABW becomes more influential on its way to the north.

Still following the $1800-\mathrm{m}$ isobath, the contribution of $W_{S B W}{ }^{S W T}$ to the water column thickness expands from $19 \mathrm{~m}$ to $72 \mathrm{~m}$ between Sections 1 and 2 (Fig. 9). This addition of WSBW ${ }^{\text {SWT }}$ might come from waters carried down the slope together with LCW. During this process part of the LCW mixes and spreads over the water column while its densest (lower) components continue to flow downslope until they reach the equilibrium depth.

As mentioned before, the OMP results indicate that the dense waters originating from Larsen $C$ reach at least the bottom layer of \#152 and \#169, located at 2400-m depth. Comparing these stations with \#176, the Larsen waters seem to influence a layer $1000 \mathrm{~m}$ thick, since the southern cast shows higher temperature and salinity, and lower oxygen below $1500 \mathrm{~m}$ than the two stations to the north (see '-[' in Fig. 5).

The increase of the dense layer thickness observed along the $1800-\mathrm{m}$ isobath and the modifications along the $2400-\mathrm{m}$ isobath are related to the formation of WSDW. This water mass is carried

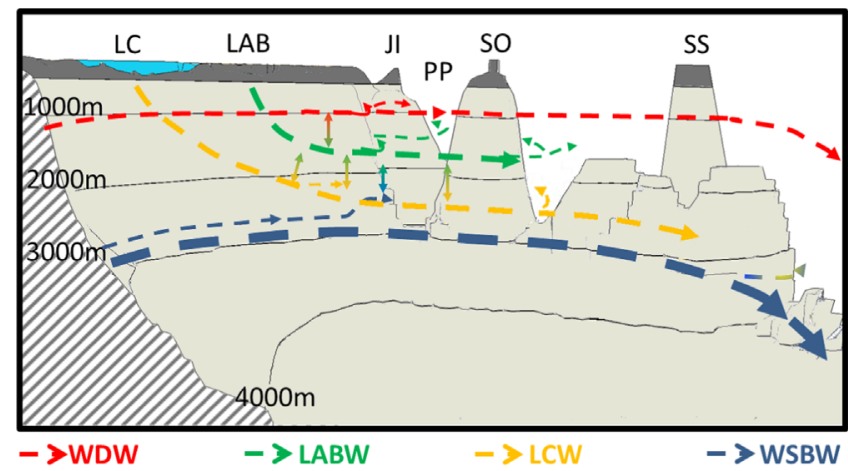

Fig. 10. Proposed mixing scheme for the formation of Antarctic Bottom Water (AABW). The flow of the Warm Deep Water (WDW, red line), Weddell Sea Bottom Water (WSBW, blue line), Larsen C Water (LCW, yellow line) and Larsen A and B Water (LABW, green line) are shown together with the main outflow paths. Abbreviations are: Joinville Island (JI), Larsen A and B (LAB), Larsen C (LC), Philip Passage (PP), South Orkney Island (SO), South Sandwich Islands (SS). (For interpretation of the references to color in this figure caption, the reader is referred to the web version of this paper.)

in the northern branch of the Weddell Gyre and might cross the South Scotia Ridge (Gordon et al., 2001) to form AABW (Fig. 10). The portion influenced by LABW is lighter and can leave the Weddell Sea through Philip Passage (Palmer et al., 2012), while the densest waters produced with LCW contributions can only cross one of the deeper channels east of the South Orkney Plateau (Figs. 1 and 10).

\section{Summary}

The production of WSDW and WSBW in the Larsen region has been suggested by different authors (e.g. Fahrbach et al., 1995; Schröder et al., 2002; Absy et al., 2008; Huhn et al., 2008). Here we propose a scheme (Fig. 10) that can explain the fresh, dense water observed at intermediate depths in the northwestern Weddell Sea (Fahrbach et al., 1995) as well as the cold and saltier lenses observed in the continental slope in front of Larsen C (Absy et al., 2008). Huhn et al. (2008) calculated a production rate of $1.1 \pm 0.5 \mathrm{~Sv}\left(1 \mathrm{~Sv}=10^{6} \mathrm{~m}^{3} \mathrm{~s}^{-1}\right)$ of WSBW in the western Weddell Sea, corresponding to $22 \%$ of the total production of this water mass $(3.9 \pm 1.2 \mathrm{~Sv}$ are produced off Filchner-Ronne Ice Shelf). In this study, no volume estimates are presented, but we show that the thickness of the dense layer increases by $70 \%$ in a short distance of $200 \mathrm{~km}$ (Figs. 6 and 9).

The contributions of the Larsen region to WSDW and WSBW can be noticed by changes in the properties of these water masses passing successive transects perpendicular to the continental slope. Other studies where the importance of the northwestern Weddell Sea for dense water production was recognized also used sections at different latitudes (Fahrbach et al., 1995; Gordon, 1998; Absy et al., 2008). If only one section is analyzed, it is unlikely that the contributions of LCW and/or the LABW are noticed, especially if it is a section to the north where these water masses are well distributed in the entire water column.

Jullion et al. (2013) concluded that the freshening of AABW in Drake Passage is related to the increased glacial loss from the Antarctic Peninsula after the breakup of Larsen A and B. No time variability was assessed in the present work, but it is clearly shown that in 2013 the waters from Robertson Trough reduced the salinity of WSDW or formed a fresher version of this water mass in Sections 2 and 3 in comparison to the WSDW coming from the south, i.e., Section 1.

Our results also show that less diluted LCW influences regions deeper than $1800 \mathrm{~m}$, with traces reaching at least to 2400-m 
depth, accounting for the densest water that can cross the South Scotia Ridge (Fig. 10). This is in agreement with the hypothesis of Schröder et al. (2002) that pulses of dense water coming from a source nearby could cause the variability observed at a mooring at 2500-m depth close to the outflow areas in the northwestern Weddell Sea (Schröder et al., 2002; von Gyldenfeldt et al., 2002).

To fully understand the production and spreading of AABW and its precursors the importance of the different sources must be understood. The evidence presented here together with previous indications clearly reveal the importance of the Larsen region.

Modelling efforts are on the way to study changes that might have huge impacts to the western Weddell Sea like the strong melting underneath the Filchner-Ronne Ice Shelf proposed by Hellmer et al. (2012). The Finite Element Sea-Ice Ocean Model (FESOM) (e.g., Wang et al., 2014) will also be used to understand the consequences of the breakup of Larsen A and B for the hydrography of the northwestern Weddell Sea and, thus, for the characteristics of AABW. Nevertheless, additional hydrographic measurements and bathymetric soundings are essential to obtain realistic results.

\section{Acknowledgment}

We would like to express our gratitude to the officers and crew of RV Polarstern for their efficient assistance during the ANTXXIX/ 3 cruise. We thank the scientific party for excellent and fruitful cooperation. Special thanks to A. Wisotzki for the outstanding care with the data sampling, for processing the oceanographic data (doi:10.1594/PANGAEA.811818), and the insightful observations during the preliminary data analysis. Thanks to J. Sültenfuß for measuring the noble gas samples, and to D. Thomas for the ISPOL oxygen measurements. The expedition ANT XXIX/3 was financed by Polarstern Grant no. PS 81/3. The first author was supported by CNPq grant 290034/2011-6. The quality of the paper was improved by the suggestions made by two anonymous reviewers.

\section{References}

Absy, J.M., Schröder, M., Muench, R., Hellmer, H.H., 2008. Early summer thermohaline characteristics and mixing in the western Weddell Sea. Deep Sea Res. Part II: Top. Stud. Oceanogr. 55, 1117-1131.

Arndt, J.E., Schenke, H.W., Jakobsson, M., Nitsche, F.O., Buys, G., Goleby, B., Rebesco, M., Bohoyo, F., Hong, J., Black, J., Greku, R., Udintsev, G., Barrios, F., ReynosoPeralta, W., Taisei, M., Wigley, R., 2013. The international bathymetric chart of the southern ocean (ibcso) version 1.0a new bathymetric compilation covering circum-antarctic waters. Geophys. Res. Lett. 40, 3111-3117.

Azaneu, M., Kerr, R., Mata, M.M., Garcia, C.A., 2013. Trends in the deep southern ocean (1958-2010): implications for antarctic bottom water properties and volume export. J. Geophys. Res.: Oceans 118, 4213-4227.

Evans, J., Pudsey, C.J., ÓCofaigh, C., Morris, P., Domack, E., 2005. Late quaternary glacial history, flow dynamics and sedimentation along the eastern margin of the antarctic peninsula ice sheet. O. Sci. Rev, 24, 741-774.

Fahrbach, E., Hoppema, M., Rohardt, G., Boebel, O., Klatt, O., Wisotzki, A., 2011. Warming of deep and abyssal water masses along the Greenwich meridian on decadal time scales: the Weddell gyre as a heat buffer. Deep Sea Res. Part II: Top. Stud. Oceanogr. 58, 2509-2523.

Fahrbach, E., Rohardt, G., Scheele, N., Schröder, M., Strass, V., Wisotzki, A., 1995 Formation and discharge of deep and bottom water in the northwestern Weddell Sea. J. Mar. Res. 53, 515-538.

Foldvik, A., Gammelsrød, T., 1988. Notes on Southern Ocean hydrography, sea-ice and bottom water formation. Palaeogeogr. Palaeoclimatol. Palaeoecol. 67, 3-17.

Foldvik, A., Gammelsrød, T., Østerhus, S., Fahrbach, E., Rohardt, G., Schröder, M. Nicholls, K.W., Padman, L., Woodgate, R.A., 2004. Ice shelf water overflow and bottom water formation in the southern Weddell Sea. J. Geophys. Res. 109, C02015.

Franco, B.C., Mata, M.M., Piola, A.R., Garcia, C.A., 2007. Northwestern Weddell se deep outflow into the scotia sea during the austral summers of 2000 and 2001 estimated by inverse methods. Deep Sea Res. Part I: Oceanogr. Res. Pap. 54, $1815-1840$
Frants, M., Gille, S.T., Hewes, C.D., Holm-Hansen, O., Kahru, M., Lombrozo, A., Measures, C.I., Mitchell, B.G., Wang, H., Zhou, M., 2013. Optimal multiparameter analysis of source water distributions in the southern drake passage. Deep Sea Res. Part II: Top. Stud. Oceanogr. 90, 31-42.

Gordon, A.L., 1998. Western Weddell Sea thermohaline stratification. Ocean Ice Atmos.: Interact. Antarct. Cont. Margin 75, 215-240.

Gordon, A.L., Huber, B.A., Hellmer, H.H., Ffield, A., 1993. Deep and bottom water of the Weddell Sea's western rim. Science 262, 95-97 〈http://www.sciencemag. org/content/262/5130/95.full.pdf .

Gordon, A.L., Visbeck, M., Huber, B., 2001. Export of Weddell Sea Deep and Bottom Water. J. Geophys. Res.: Oceans (1978-2012) 106, 9005-9017.

Graeve, M., Bohlmann, H., Fillinger, L., Gerdes, D., Knust, R., 2013. Physical Oceanography During Polarstern Cruise ANT-XXVII/3 (PS77, CAMBIO).

Gutt, J., Schröder, M., Sieger, V., 2013. The expedition of the research vessel Polarstern to the antarctic in 2013 (ANT-XXIX/3). Rep. Polar Mar. Res. 665, 151.

von Gyldenfeldt, A., Fahrbach, E., García, M., Schröder, M., 2002. Flow variability at the tip of the antarctic peninsula. Deep Sea Res. Part II: Top. Stud. Oceanogr. 49, 4743-4766.

Hellmer, H., Schröder, M., Haas, C., Dieckmann, G., Spindler, M., 2008. The ISPOL drift experiment. Deep Sea Res. Part II: Top. Stud. Oceanogr. 55, 913-917.

Hellmer, H.H., Kauker, F., Timmermann, R., Determann, J., Rae, J., 2012. Twentyfirst-century warming of a large antarctic ice-shelf cavity by a redirected coastal current. Nature 485, 225-228. http://dx.doi.org/10.1038/nature11064.

Huhn, O., Hellmer, H.H., Rhein, M., Rodehacke, C., Roether, W., Schodlok, M.P., Schröder, M., 2008. Evidence of deep- and bottom-water formation in the western Weddell Sea. Deep Sea Res. Part II: Top. Stud. Oceanogr. 55, 1098-1116.

Jullion, L., Naveira Garabato, A.C., Meredith, M.P., Holland, P.R., Courtois, P., King, B. A., 2013. Decadal freshening of the Antarctic Bottom Water exported from the Weddell Sea. J. Clim., 8111-8125.

Karstensen, J., Tomczak, M., 1995. Omp Analysis Package for Matlab Version 2.0. 〈http://omp.ifm-geomar.de/〉(downloaded in 2013).

Knust, R., 2012. Expeditionsprogramm nr. 90, FS Polarstern, ANT-XXIX/1, ANT-XXIX/ 2, ANT-XXIX/3. Expeditionsprogramm Polarstern.

Lemke, P., 2009. The expedition of the research vessel "Polarstern" to the antarctic in 2006 (ANT-XXIII/7). Rep. Polar Mar. Res. 586.

Lumpkin, R., Speer, K., 2007. Global ocean meridional overturning. J. Phys. Oceanogr. 37, 2550-2562.

Mackas, D.L., Denman, K.L., Bennett, A.F., 1987. Least squares multiple tracer analysis of water mass composition. J. Geophys. Res.: Oceans 92, 2907-2918.

Naveira Garabato, A.C., McDonagh, E.L., Stevens, D.P., Heywood, K.J., Sanders, R.J., 2002. On the export of Antarctic Bottom Water from the Weddell Sea. Deep Sea Res. Part II: Top. Stud. Oceanogr. 49, 4715-4742.

Nicholls, K., Pudsey, C., Morris, P., 2004. Summertime water masses off the northern Larsen C ice shelf, antarctica. Geophys. Res. Lett. 31, L09309.

Nicholls, K.W., Østerhus, S., Makinson, K., Gammelsrod, T., Fahrbach, E., 2009. Iceocean processes over the continental shelf of the southern Weddell Sea Antarctica: a review. Rev. Geophys. 47, RG3003.

Orsi, A.H., Johnson, G.C., Bullister, J.L., 1999. Circulation, mixing, and production of Antarctic Bottom Water. Progr. Oceanogr. 43, 55-109.

Palmer, M., Gomis, D., del Mar Flexas, M., Jordà, G., Jullion, L., Tsubouchi, T., Garabato, A.C.N., 2012. Water mass pathways and transports over the south scotia ridge west of $50^{\circ} \mathrm{W}$. Deep Sea Res. Part I: Oceanogr. Res. Pap. 59, 8-24.

Purkey, S.G., Johnson, G.C., 2013. Antarctic bottom water warming and freshening: contributions to sea level rise, ocean freshwater budgets, and global heat gain*. J. Clim. 26, 6105-6122.

Schröder, M., Hellmer, H.H., Absy, J.M., 2002. On the near-bottom variability in the northwestern Weddell Sea. Deep Sea Res. Part II: Top. Stud. Oceanogr. 49, 4767-4790.

Schröder, M., Wisotzki, A., van Caspel, M., 2013a. Physical oceanography during POLARSTERN cruise ANT-XXIX/3. Technical Report, Alfred Wegener Institute, Helmholtz Center for Polar and Marine Research, Bremerhaven.

Schröder, M., Wisotzki, A., van Caspel, M., 2013b. Physical oceanography measured on water bottle samples during POLARSTERN cruise ANT-XXIX/3. Technical Report, Alfred Wegener Institute, Helmholtz Center for Polar and Marine Research, Bremerhaven.

Sültenfuß, J., Roether, W., Rhein, M., 2009. The bremen mass spectrometric facility for the measurement of helium isotopes, neon, and tritium in water. Isot. Environ. Health Stud. 45, 83-95.

Timmermann, R., Le Brocq, A., Deen, T., Domack, E., Dutrieux, P., Galton-Fenzi, B., Hellmer, H., Humbert, A., Jansen, D., Jenkins, A., et al., 2010. A consistent data set of antarctic ice sheet topography, cavity geometry, and global bathymetry. Earth Syst. Sci. Data 2, 261-273.

Tomczak, M., 1981. A multi-parameter extension of temperature/salinity diagram techniques for the analysis of non-isopycnal mixing. Progr. Oceanogr. 10, $147-171$.

Tomczak, M., Large, D.G., 1989. Optimum multiparameter analysis of mixing in the thermocline of the eastern indian ocean. J. Geophys. Res. 94, pp. 16141-16.

Wang, Q., Danilov, S., Sidorenko, D., Timmermann, R., Wekerle, C., Wang, X., Jung, T., Schröter, J., 2014. The finite element sea ice-ocean model (FESOM) v.1.4: formulation of an ocean general circulation model. Geosci. Model Dev. 7, 663-693. 